\title{
Program Pendampingan Usaha Rak Pot Bunga di SMKN 1 Cipunagara
}

\author{
Aurelia Beryl Foustine1, Erick Widjaya ${ }^{2}$, I Putu Krisna ${ }^{3}$, Richelin Anggraini ${ }^{4}$, \\ Valencia Kusanto ${ }^{5}$, Novira da Silva ${ }^{6}$ \\ 1, 2,4,5,6 SBE Universitas Prasetiya Mulya \\ e-mail: 1aurelia.foustine@student.pmsbe.ac.id, 2erick.widjaya@student.pmsbe.ac.id, \\ ${ }^{4}$ richelin.anggriani@student.pmsbe.ac.id, ${ }^{5}$ valencia.kusanto@student.pmsbe.ac.id, \\ ${ }^{6}$ novira.dasilva@pmbs.ac.id \\ ${ }^{3}$ STEM Universitas Prasetiya Mulya \\ e-mail: ${ }^{3}$ i.krisna@student.pmsbe.ac.id
}

\begin{abstract}
Abstrak
Tujuan program pengabdian masyarakat adalah mendampingi mitra usaha dari SMKN 1 Cipunagara mengembangkan usaha rak pot bunga sebagai salah satu UMKM yang memiliki potensi untuk berkembang selama pandemi. Tim penulis mengidentifikasi masalah yang dihadapi mitra yaitu kurang nya pengetahuan dalam hal pencatatan keuangan, kegiatan pemasaran, kurangnya prosedur kerja sistematis dan terbatasnya minat berusaha dan untuk berbisnis. Tim penulis melakukan program pendampingan Community Development melalui media daring dengan aplikasi google meet dan komunikasi dilakukan melalui aplikasi pesan singkat whatsapp grup. Temuan tim penulis adalah aspek keuangan, pemasaran dan produksi mitra usaha belum dijalankan secara profesional. Analisis terhadap permasalahan yang dialami mitra dilakukan dengan menggunakan konsep SWOT dan aplikasinya dalam TOWS Matriks, untuk mencari strategi yang cocok dalam menghadapi permasalahan mitra. Solusi yang diajukan oleh tim penulis kepada mitra berupa pendampingan pencatatan dan pengelolaan keuangan, pembuatan jalur pemasaran menggunakan media digital dan perumusan standar operasi prosedur kegiatan produksi. Rekomendasi penulis bagi program di masa mendatang adalah waktu pelaksanaan program tidak bersamaan dengan periode ujian sekolah.
\end{abstract}

Kata Kunci: Pendampingan, Mitra Usaha SMKN, TOWS Matrix

\section{Abstract}

The purpose of the community service program is to assist business partners from SMKN 1 Cipunagara in developing a flower pot rack business as one of potential business unit during the pandemic. The authors identified problems faced by business partners as follows, lack of financial recording, marketing activities, inadequate of systematic operating procedure and shortage of entrepreneurial mindset. Community Development Program is conducted through online media with the Google Meet application and communication by means of WhatsApp group short message application. The findings are managerial functions consist of financial, marketing, and production have not been carried out professionally in business partner activities. Authors used SWOT framework analysis and its application in the TOWS Matrix, to find suitable strategies in dealing with partner's problems. The solutions proposed by authors 
are financial recording and management assistance, creating marketing channels using digital media, and formulating standard operating procedures for production activities. The author's recommendation for the program in the future is on the implementation timeline avoiding national school exam period.

Keywords: community development, Highschool business partner, TOWS Matrix

\section{Pendahuluan}

Sejak kuartal pertama tahun 2020, pandemi COVID-19 telah memberikan dampak negatif kepada kinerja ekonomi di Indonesia. Penurunan profitabilitas tidak hanya berdampak pada perusahaan besar saja, tetapi juga di tingkat UMKM. Menurut survey yang telah dilakukan oleh Badan Pusat Statistik di bulan Juli 2020, sebanyak $84,2 \%$ UMKM telah mengalami penurunan pendapatan. Usaha - usaha yang biasanya menggunakan cara konvensional untuk melakukan penjualan sekarang sepi pembeli dikarenakan penurunan daya beli masyarakat dan intensitas masyarakat untuk keluar rumah. Data tersebut juga menyebutkan 38,75\% masyarakat menyatakan lebih jarang keluar rumah, selain untuk kewajiban pekerjaan dan 32,25\% masyarakat mengalami penurunan pengeluaran (Badan Pusat Statistik, 2020).

Salah satu UMKM yang memiliki potensi usaha untuk berkembang adalah usaha yang dikelola oleh SMKN 1 Cipunagara dengan jenama 'Juragan Muda Nescip'. SMK Negeri 1 Cipunagara merupakan Sekolah Menengah Kejuruan yang terletak di kecamatan Cipunagara, Kabupaten Subang, Jawa Barat, bertindak sebagai mitra usaha program Community Development (COMDEV) Universitas Prasetiya Mulya Tahun 2021. SMKN 1 Cipunagara memiliki 1026 peserta didik aktif dengan 7 jurusan kompetensi keahlian, yaitu Teknik dan Bisnis Sepeda Motor, Teknik Kendaraan Ringan Otomotif, Teknik Komputer dan Jaringan, Teknik Elektronika Industri, Teknik Pemesinan, Tata Kelola Perkantoran dan Akuntasi Keuangan. Jurusan Teknik Pemesinan menjadi mitra kegiatan COMDEV 2021, dimana produk usaha yang dihasilkan salah satunya adalah rak pot bunga yang dipasarkan dengan kisaran harga Rp 50.000-3000.000 per buah.

Analisis SWOT adalah penilaian menyeluruh terhadap kekuatan, kelemahan, peluang, dan ancaman yang dihadapi suatu organisasi (Schermerhorn \& Bachrach, 2015). Langkah pertama, sumber daya dan kemampuan internal organisasi dievaluasi melalui kekuatan dan kelemahannya sehingga dapat ditemukan kompetensi utama dari bisnis. Langkah kedua, peluang dan ancaman dari lingkungan di sekitar organisasi dievaluasi. TOWS matriks merupakan aplikasi dari analisis SWOT untuk mencocokkan faktor internal dan eksternal organisasi serta menciptakan strategi yang dapat dilakukan oleh perusahaan (Lynch, 2020). Analisis SWOT dan TOWS matriks berguna untuk mengevaluasi organisasi dan kondisi lingkungannya.

Pemasaran digital atau Digital Marketing adalah penggunaan berbagai bentuk interaksi dengan konsumen, tidak hanya mengandalkan pada website. Interaksi tersebut bisa diperoleh dari pengelolaan elemen 5D berikut (Chaffey \& EllisChadwick, 2015): 
a. Digital Device: adalah berbagai perangkat digital. Internet memudahkan koneksi dan kombinasi penggunaan perangkat digital seperti smartphone, tablet, laptop, desktop computer, TV dan virtual assistant.

b. Digital Platform: adalah interaksi antar gawai dapat terjadi melalui aplikasi pada layanan platform seperti Google, Youtube, Instagram, Twitter, dan lainnya.

c. Digital Media: berbagai media komunikasi dapat digunakan untuk meraih kelekatan dengan konsumen seperti penggunaan media iklan, email, pesan singkat, sosial media, dan lainnya.

d. Digital Data: data dan profil konsumen yang berinteraksi dengan sebuah usaha dapat dengan mudah diakses dan dikelola

e. Digital Technology: penggunaan teknologi untuk kegiatan pemasaran dimana sebuah usaha menggunakan cara-cara kreatif untuk menciptakan pengalaman berinteraksi di website, aplikasi di telepon genggam, dan toko fisik.

Pengelolaan berbagai elemen dalam digital marketing akan membantu UMKM tumbuh dan berkembang dengan lebih baik terutama di masa pandemi COVID-19 (Fitriasari, 2020).

\section{Tujuan dan Manfaat kegiatan Pendampingan}

Rak pot bunga menjadi salah satu karya peserta didik jurusan Teknik Pemesinan. Saat ini keahlian yang dimiliki siswa dan pengajar hanya terbatas pada aspek teknis produksi, dan masih memiliki kelemahan di aspek pemasaran, keuangan dan minimnya pengalaman dalam mengelola suatu usaha. Program COMDEV pengembangan wirausaha ini bertujuan untuk meningkatkan penjualan dari produk rak pot bunga dan mengembangkan usaha Juragan Muda Nescip. Usaha ini memiliki potensi untuk berkembang dengan mengimplementasikan solusi yang telah dibagikan dalam kegiatan pengabdian masyarakat ini.

Selain tujuan, adapun beberapa manfaat yang didapatkan oleh mitra sebagai berikut:

a. Melatih dan membantu SMKN 1 Cipunagara dalam mengembangkan wirausahanya, khususnya untuk produk rak pot bunga.

b. Memberdayakan peserta didik serta guru SMKN 1 Cipunagara melalui pelatihan dan workshop, sehingga dapat mengembangkan dan menjalankan usahanya secara mandiri.

c. Meningkatkan ekonomi mitra, sehingga dapat meningkatkan motivasi mitra dalam menjalankan usahanya.

\section{Identifikasi Permasalahan Mitra}

Berdasarkan pertemuan yang telah dilakukan secara daring dengan SMKN 1 Cipunagara, ditemukan beberapa permasalahan yang sedang terjadi di usaha mitra. Pertama, pengetahuan mitra hanya terbatas pada bidang teknis operasional saja, sehingga aspek lain tidak dimaksimalkan. Saat ini usaha rak pot bunga hanya dijalankan oleh jurusan teknik pemesinan saja, padahal siswa-siswi jurusan lain bisa diikutsertakan untuk belajar mengelola keuangan, pemasaran, dan SDM. Keberadaan usaha yang dikembangkan oleh SMKN 1 Cipunagara ini juga masih belum diketahui oleh banyak orang, dikarenakan penyebaran informasi dan pemasaran produk masih 
belum dilakukan. Kedua, masyarakat luas sebagai calon konsumen potensial belum mengetahui tentang produk dan usaha ini. Berdasarkan hasil wawancara dengan Bapak Syafri Ali selaku penanggung jawab usaha Juragan Muda Nescip, sejauh ini konsumen mengetahui keberadaan usaha Juragan Muda Nescip dari mulut ke mulut melalui siswa kepada tetangga maupun kerabat mereka. Sebagian besar konsumen berasal dari kalangan ibu rumah tangga yang memiliki keinginan untuk menghias rumah mereka dengan berbagai dekorasi interior. Ketiga, distribusi produk juga menjadi permasalahan terkait dengan ukuran volume produk, sehingga ongkos kirim keluar kota atau area yang cukup jauh menjadi cukup tinggi. Terakhir, pada sisi pencatatan keuangan masih dilakukan secara manual dan seadanya oleh 4 siswa SMKN 1 Cipunagara, sering terjadi salah pencatatan dan menghasilkan laporan yang tidak konsisten. Permasalahan mitra ini selaras dengan permasalah yang dialami oleh UMKM pemula pada umumnya yaitu pengelolaan keuangan, dan pemasaran produk termasuk didalamnya adalah penggunaan kemasan (Mudjijah \& Anggraini, 2021).

\section{Metode}

Kegiatan COMDEV 2021 dilaksanakan secara daring, seiring dengan kegiatan pembelajaran jarak jauh selama masa pandemi covid-19. Kelompok mahasiswa yang bermitra dengan SMKN 1 Cipunagara adalah kelompok nomor 008 (selanjutnya disebut tim penulis). Kelompok ini beranggotakan 4 mahasiswa dari Sekolah Bisnis dan 1 mahasiswa dari Sekolah Teknik Universitas Prasetiya Mulya. Ada dua kegiatan utama selama kegiatan pendampingan mitra COMDEV, yaitu pendampingan intensif dan pendampingan lanjutan. Pendampingan intensif dilakukan melalui panggilan video dengan platform Google Meet bersama mitra selama 5 (lima) jam per minggu. Pendampingan intensif berlangsung selama bulan Februari 2021, dan kelompok juga mengadakan kegiatan Lokakarya secara online melalui Zoom Platform dengan tujuan untuk memberikan wawasan terkait kewirausahaan kepada mitra. Setelah melewati pendampingan intensif, tim penulis melanjutkan pendampingan lanjutan yang dilakukan dari awal Maret hingga akhir Juni 2021 dengan waktu pertemuan minimal 1 (satu) kali pertemuan tiap bulan untuk konsultasi dan evaluasi perkembangan usaha mitra.

Penanggung jawab usaha mitra yang ditunjuk oleh pihak SMKN 1 adalah Bapak Syafri Ali selaku ketua dari usaha Juragan Muda Nescip. Tim Usaha mitra terdiri dari siswa kelas XII, dan 2 guru yang ditunjuk menjadi penanggung jawab keuangan dan pemasaran. Komunikasi antara tim penulis dan tim mitra juga dilakukan melalui pesan singkat dalam Grup Whatsapp (WA). Grup WA sangat berguna untuk mempermudah komunikasi kedua belah pihak ketika sedang tidak memiliki waktu kosong untuk melakukan pertemuan daring di media google meet.

Dalam memperoleh data yang dibutuhkan oleh tim penulis, terdapat 2 (dua) metode yang digunakan yaitu wawancara dan observasi partisipatif dengan mitra secara daring. Metode observasi partisipatif adalah ketika tim penulis ikut berpartisipasi dalam analisis situasi internal dan eksternal mitra usaha dalam kaitannya dengan penyusunan strategi usaha mitra. 


\section{Hasil dan Pembahasan}

Pendampingan kegiatan kewirausahaan yang dilakukan oleh tim penulis dimulai dengan identifikasi terhadap kondisi internal dan eksternal usaha mitra yang dirumuskan dalam TOWS Matriks. Tahap selanjutnya, analisis permasalahan yang dihadapi mitra dari sisi keuangan, pemasaran digital, dan kegiatan produksi.

\section{Analisis SWOT Usaha Mitra}

Analisis Situasi Internal berasal dari kekuatan dan kelemahan usaha mitra. Analisis Situasi Eksternal berasal dari peluang dan ancaman yang mungkin akan dihadapi di masa yang akan datang. Berdasarkan analisis situasi internal dan eksternal, lalu dibuatlah matrik TOWS yang menggabungkan kedua komponen tersebut, yaitu:

a. Kekuatan dan Peluang (Strength Opportunity)

b. Kekuatan dan Ancaman (Strength Threat)

c. Kelemahan dan Peluang (Weakness Opportunity)

d. Kelemahan dan Ancaman (Weakness Threat)

Matrik TOWS menjadi dasar bagi tim penulis untuk mengalokasikan sumber daya yang dimiliki oleh mitra untuk menjadi dasar strategi usaha yang akan dijalankan. Matrik TOWS Mitra dapat dilihat pada tabel 1. Sejalan dengan penelitian sebelumnya analisis SWOT dilakukan untuk merumuskan strategi pengembangan usaha mikro milik mahasiswa (Rosyadi, 2013), dan perbaikan bisnis proses pada tingkat UMKM dengan menerapkan prinsip lean dan continuos improvement (Almanei et al., 2017; Pearce et al., 2018).

Tabel 1. TOWS Matrix Mitra

\begin{tabular}{|c|c|c|}
\hline & FAKTOR INTERNAL & \\
\hline TOWS MATRIX & $\begin{array}{l}\text { Strength }(\mathbf{S}) \\
\text { 1. Mahir dalam penggunaan } \\
\text { alat-alat produksi mesin. } \\
\text { 2. Desain produk dapat di } \\
\text { sesuaikan dengan } \\
\text { permintaan pembeli. } \\
\text { 3. Harga yang ditawarkan } \\
\text { dapat bersaing dengan } \\
\text { kompetitor. }\end{array}$ & $\begin{array}{l}\text { Weakness }(\mathbf{W}) \\
\text { 1. Kurangnya pengalaman } \\
\text { dalam mengelola usaha. } \\
\text { 2. Kemampuan terbatas } \\
\text { pada teknis operasional } \\
\text { saja, dan minim } \\
\text { pengetahuan pada } \\
\text { fungsi manajemen } \\
\text { lainnya. } \\
\text { 3. Dimensi produk besar } \\
\text { jika dikirim keluar } \\
\text { daerah. } \\
\text { 4. Teknologi produksi } \\
\text { yang digunakan masih } \\
\text { sederhana dan terbatas. }\end{array}$ \\
\hline
\end{tabular}




\begin{tabular}{|c|c|c|c|}
\hline & $\begin{array}{l}\text { Opportunity }(\mathbf{O}) \\
\text { 1.Sedang marak } \\
\text { tren menghias } \\
\text { rumah dengan } \\
\text { tanaman } \\
\text { berbunga } \\
\text { 2. Pasar yang } \\
\text { lebih mudah } \\
\text { dijangkau } \\
\text { karena } \\
\text { zamannya } \\
\text { serba digital. }\end{array}$ & $\begin{array}{l}\text { SO:SO Strategies } \\
\begin{array}{l}\text { 1. Pemasaran lewat channel } \\
\text { e-commerce dengan harga } \\
\text { terjangkau. } \\
\text { 2. Melakukan riset pasar dan } \\
\text { membuat model rak yang } \\
\text { digemari konsumen. } \\
\text { 3. Memberikan custom } \\
\text { bentuk karangan rak pot } \\
\text { bunga kepada konsumen } \\
\text { untuk mendukung mereka } \\
\text { menghias rumah dengan } \\
\text { tanaman. }\end{array}\end{array}$ & $\begin{array}{l}\text { WO:WO Strategies } \\
\text { 1. Memberikan training } \\
\text { pengelolaan fungsi } \\
\text { menajemen pemasaran, } \\
\text { operasional untuk usaha. } \\
\text { 2. Menjangkau pasar yang } \\
\text { lebih luas melalui } \\
\text { pemasaran digital khusus } \\
\text { usaha rak pot bunga } \\
\text { yang sedang tren di masa } \\
\text { COVID-19 ini. } \\
\text { 3. Memperkecil volume } \\
\text { produk, atau membuat } \\
\text { produk sistem bongkar } \\
\text { pasang, sehingga barang } \\
\text { dapat dikirim } \\
\text { menggunakan jasa kirim } \\
\text { ke luar daerah. }\end{array}$ \\
\hline $\begin{array}{l}\text { EKSTER } \\
\text { NAL }\end{array}$ & $\begin{array}{l}\text { Threats }(\mathrm{T}) \\
\text { 1.Saingan } \\
\text { penjual rak pot } \\
\text { bunga di kota } \\
\text { besar. } \\
\text { 2. Persaingan di } \\
\text { e-commerce } \\
\text { yang sengit } \\
\text { karena jumlah } \\
\text { penjual yang } \\
\text { banyak dengan } \\
\text { varian jenis } \\
\text { produk rak pot } \\
\text { bunga yang } \\
\text { beragam. } \\
\text { 3. Produk mudah } \\
\text { ditiru oleh } \\
\text { pesaing. }\end{array}$ & $\begin{array}{l}\text { ST:ST Strategies } \\
\begin{array}{l}\text { 1. Melakukan inovasi produk } \\
\text { rak pot bunga yang } \\
\text { memiliki nilai tambah dan } \\
\text { keunikan daripada } \\
\text { pesaing. } \\
\text { 2. Harga lebih murah } \\
\text { sehingga mudah } \\
\text { melakukan konsinyasi } \\
\text { lewat pedagang tanaman } \\
\text { di kota untuk memperluas } \\
\text { jangkauan konsumen } \\
\text { sekaligus meningkatkan } \\
\text { penjualan. } \\
\text { 3. Menyediakan varian } \\
\text { produk yang beragam. }\end{array}\end{array}$ & $\begin{array}{l}\text { WT:WT Strategies } \\
\text { 1. Melakukan pelatihan } \\
\text { manajemen bisnis dari } \\
\text { aspek keuangan, } \\
\text { pemasaran untuk } \\
\text { pengelolaan keuangan } \\
\text { dan pemasaran untuk } \\
\text { meningkatkan daya } \\
\text { saing. } \\
\text { 2. Memperkecil volume } \\
\text { produk dengan cara } \\
\text { sistem bongkar pasang, } \\
\text { sehingga dapat } \\
\text { menyaingi penjual rak } \\
\text { pot bunga di e-commerce. } \\
\text { 3. Melakukan inovasi } \\
\text { produk rak pot bunga } \\
\text { yang inovatif dan kreatif } \\
\text { sehingga tidak kalah } \\
\text { dengan produk-produk } \\
\text { pesaing. }\end{array}$ \\
\hline
\end{tabular}

Analisis SWOT Matrix yang dilakukan oleh kelompok mengidentifikasi kekuatan, kelemahan, peluang dan tantangan yang mungkin akan dihadapi oleh Juragan Muda Nescip. Kemudian, TOWS Matrix digunakan untuk membantu formulasi strategi yang dapat dilakukan untuk mengatasi tantangan dan memanfaatkan peluang yang dihadapi oleh mitra. Hasil identifikasi strategi yang diperoleh dari analisis SWOT dan TOWS diterapkan dan dijelaskan secara lebih terperinci dalam tiap aspek manajemen Juragan Muda Nescip. Melalui analisis SWOT dan TOWS Matrix, tim penulis dapat memformulasikan dan menjalankan strategi yang sesuai dengan kondisi mitra dalam setiap aspeknya. 


\section{Aspek Keuangan}

Keadaan awal pencatatan keuangan dari usaha mitra masih dilakukan secara sederhana dan dilakukan sepenuhnya oleh oleh personil dari jurusan pemesinan yang kurang memiliki kemampuan melakukan pembukuan. Pihak sekolah memberikan dukungan pendanaan dan mitra mencatat segala transaksi di buku besar secara manual (gambar 1). Personil yang bertanggungjawab terhadap pencatatan keuangan juga sering tidak langsung mencatatkan transaksi, dan harus diingatkan beberapa hari setelah transaksi terjadi. Proses penentuan harga dan perhitungan biaya produksi dilakukan hanya dengan perkiraan saja. Tim penulis menilai mitra memiliki kekurangan dalam mengelola pencatatan keuangan usaha.

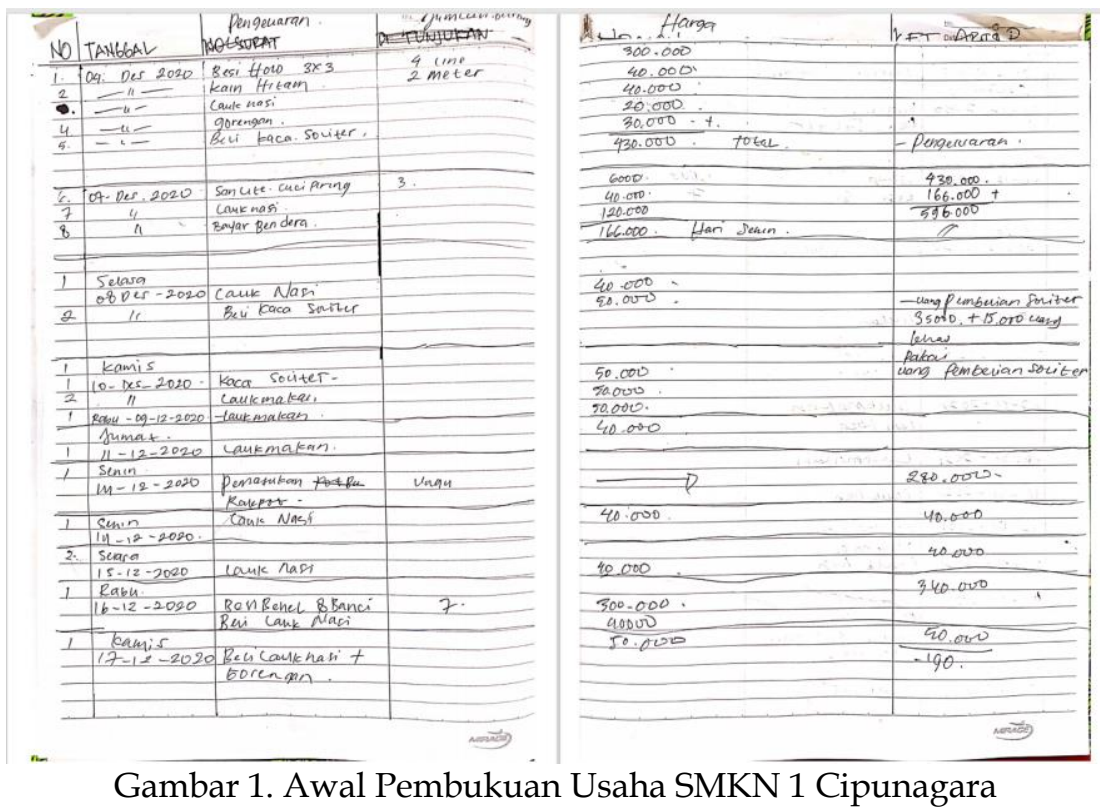

\section{Perbaikan strategi keuangan}

Tim penulis merumuskan dua strategi untuk memperbaiki kondisi keuangan mitra sesuai dengan poin pada matriks TOWS kolom WT Strategies, yaitu memberikan pelatihan aspek keuangan. Pertama, melakukan pelatihan dan pembuatan pembukuan yang komprehensif mencakup pembuatan jurnal umum, buku besar, laporan laba rugi, neraca, dan laporan arus kas dengan bendahara khusus unit usaha SMKN 1 Cipunagara (gambar 2). Melalui strategi tersebut, mitra dapat mengetahui kondisi finansial usahanya secara mendetail dan melakukan pengelolaan keuangan. Kedua, melakukan pelatihan manajemen keuangan bersama seluruh anggota unit usaha mitra. Topik manajemen keuangan yang diajarkan dikhususkan untuk menghitung biaya-biaya dalam harga pokok penjualan, menghitung titik impas dalam penentuan jumlah penjualan minimum, dan mengidentifikasi komponen penetapan harga. Pelatihan manajemen keuangan ditujukan agar mitra dapat mengambil keputusan keuangan lebih baik dan mengetahui keuntungan yang diperoleh dari setiap produk. Terakhir, tim penulis menyiapkan format Excel untuk membantu mitra melakukan pencatatan keuangan. Tim penulis juga melakukan audit sederhana untuk mengevaluasi pelaksanaan kedua strategi utama tersebut. 


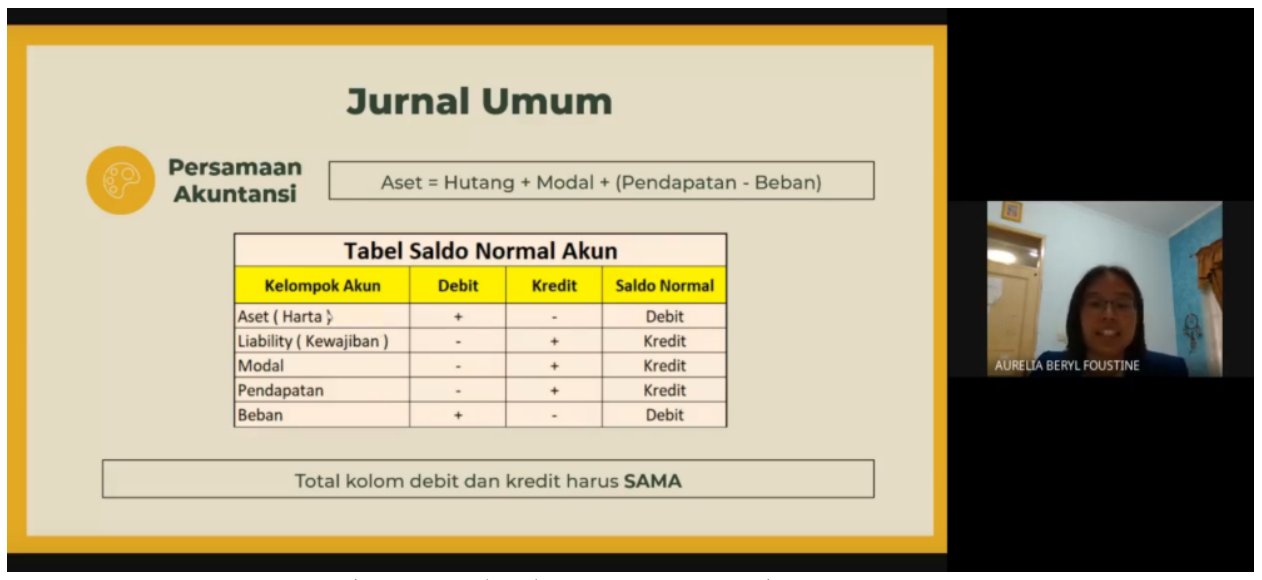

Gambar 2. Pelatihan Keuangan bersama Mitra

\section{Dampak perubahan keuangan}

Pengimplementasian strategi keuangan dijalankan selama 4 bulan dan berjalan dengan lancar. Setelah menjalankan beberapa kali pertemuan pelatihan keuangan, anggota unit usaha SMKN 1 Cipunagara menjadi sadar akan pentingnya pengelolaan keuangan bagi keberlangsungan usaha. Saat ini, terdapat seorang guru yang menjadi bendahara khusus unit usaha yang melakukan pencatatan terhadap seluruh transaksi keuangan. Pembukuan sudah mencakup jurnal umum hingga laporan arus kas. Pencatatan dilakukan menggunakan aplikasi Microsoft Excel dengan template yang telah disediakan oleh tim penulis (gambar 3). Kemudian, mitra yang sebelumnya menentukan harga dan biaya dengan perkiraan saja telah melakukan perhitungan secara mendetail dari biaya variabel hingga biaya penjualan dan dapat menentukan harga yang sesuai untuk menjamin profitabilitasnya. Alhasil, mitra telah mampu melakukan pembukuan komprehensif dan manajemen keuangan dengan lebih baik.

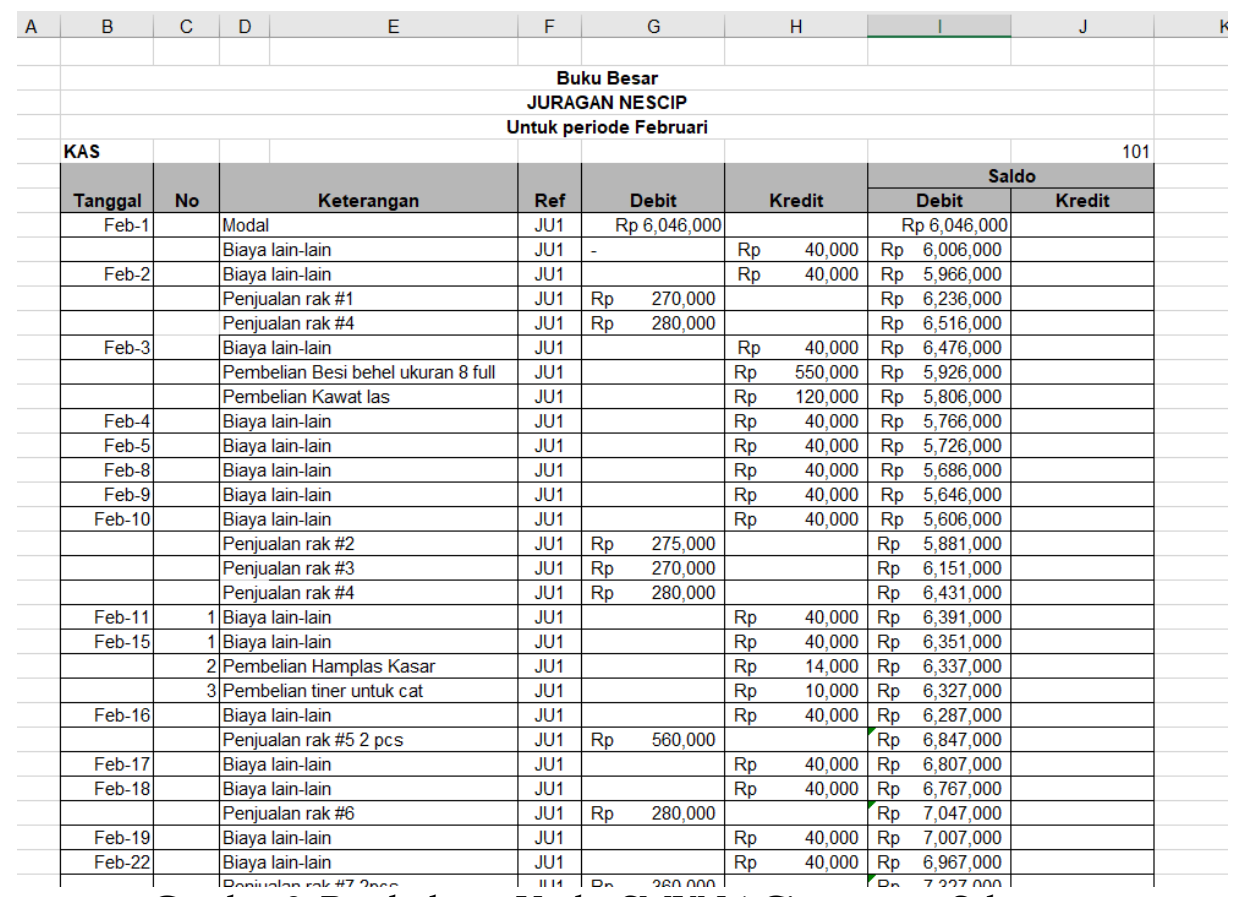

Gambar 3. Pembukuan Usaha SMKN 1 Cipunagara Sekarang 
Pelatihan otomisasi pembukuan dengan aplikasi Microsoft Excel serta pengumpulan bukti transaksi sejalan dengan penelitian sebelumnya terkait literasi keuangan pada UMKM (Mulyani et al., 2019; Septiani et al., 2020). Sebuah usaha yang telah mampu mengidentifikasi kondisi dan posisi keuangan usahanya diharapkan dapat meningkatkan daya saing usaha.

\section{Aspek Pemasaran}

\section{Keadaan Awal Pemasaran}

Di awal pengamatan tim penulis, SMK Negeri 1 Cipunagara hanya memiliki sosial media berupa instagram tetapi belum memiliki isi instagram produk yang beragam. Strategi pemasaran yang dilakukan selama ini masih berupa word of mouth (dari mulut ke mulut) yang dilakukan sekitar daerah Cipunagara.

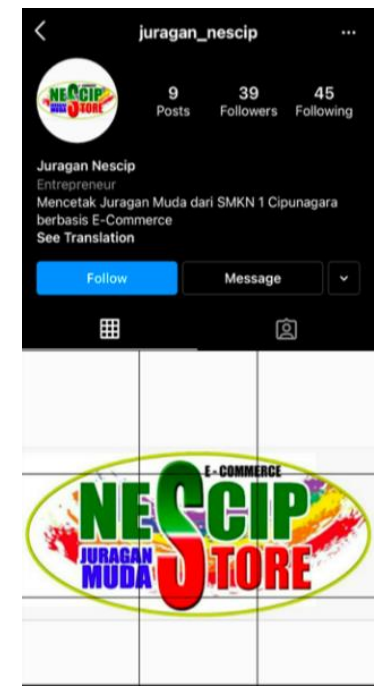

Gambar 4. Tampilan Instagram Awal Nescip Store

\section{Perbaikan strategi pemasaran}

SMK Negeri 1 Cipunagara melakukan pengembangan dalam strategi marketing dengan dibantu tim penulis. Pengembangan yang dilakukan adalah pembuatan website untuk meletakan informasi produk dan SMK Negeri 1 Cipunagara, ecommerce shopee untuk melakukan transaksi penjualan produk, dan mengubah tampilan sosial media instagram agar lebih sesuai untuk kepentingan bisnis seperti terlihat pada gambar 5. Logo Nescip Store diubah dengan dominan warna hijau dan putih.

Penggunaan berbagai layanan aplikasi digital dan media ini sejalan dengan pengelolaan 5D dalam pemasaran digital (Chaffey \& Ellis-Chadwick, 2015) dan penerapan penggunaan sosial media dalam membangun kesadaran akan jenama produk (Oktaviani \& Rustandi, 2018). Implementasi pemasaran digital (website dan Instagram yang dikelola mandiri) juga sangat membantu meningkatkan kesadaran akan merek (Azizah \& Mauliana, 2020; Oktaviani \& Rustandi, 2018). Beberapa kegiatan ini adalah implementasi dari strategi yang telah dirumuskan dalam TOWS Matrix di kolom SO dan WO Strategies yaitu menjangkau pasar digital. 


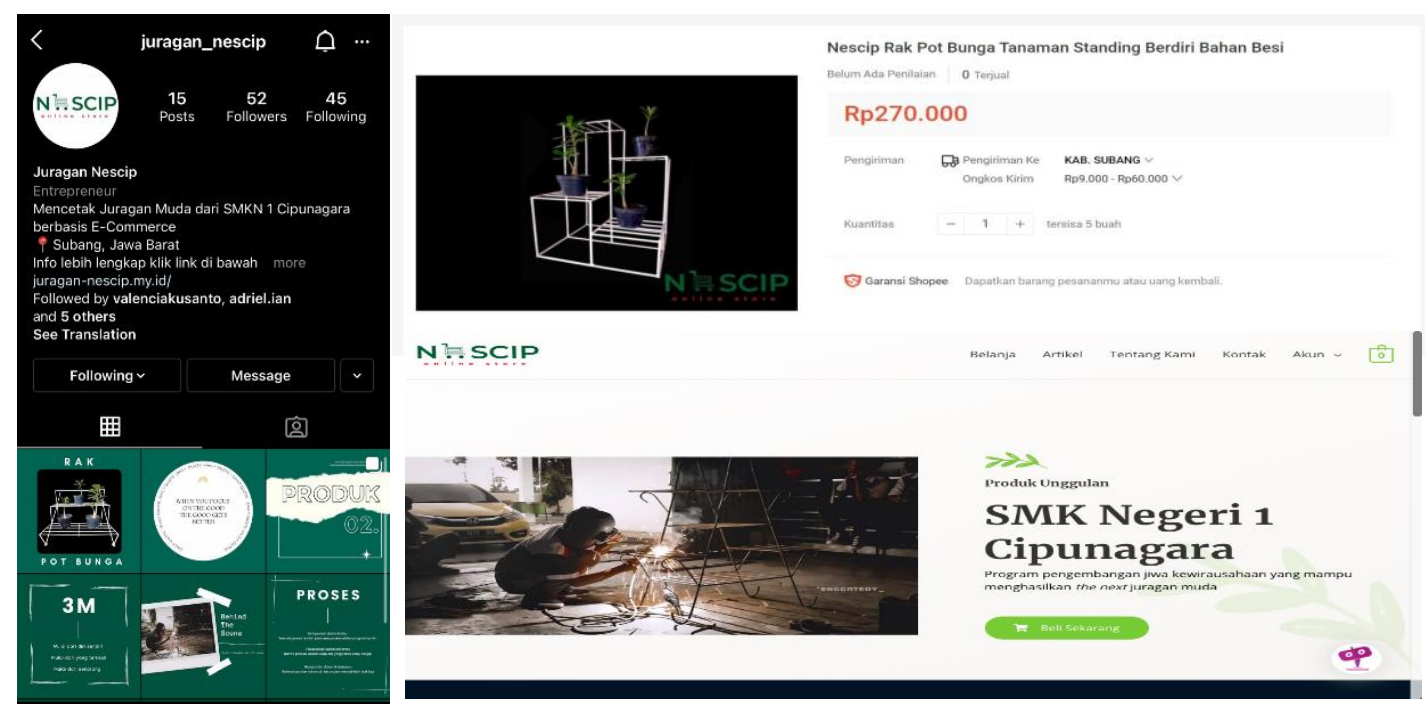

Gambar 5. Tampilan Instagram, Website, dan Shopee dari Nescip Store

\section{Dampak perubahan pemasaran}

Dengan adanya perubahan strategi marketing, SMK Negeri 1 Cipunagara dapat mengefisiensikan waktu untuk promosi meskipun tetap diiringi word of mouth (dari mulut ke mulut) yang sesuai dengan kondisi wilayah Cipunagara. Strategi tersebut juga membuat usaha Nescip Store lebih terlihat profesional dan terpercaya serta mendapatkan reputasi yang lebih baik dimata konsumen. Dengan dikembangkannya pemasaran digital maka kesadaran masyarakat akan terhadap Nescip Store semakin meningkat. Hal ini dapat dilihat dari peningkatan follower yang terjadi di akun sosial media instagram Nescip. Perkembangan di berbagai media pemasaran digital ini membantu mitra dalam mengambil keputusan untuk pengembangan usaha.

\section{Aspek Operasional}

\section{Keadaan awal operasional}

Pada awal kegiatan operasional sebelum program Community Development, anggota produksi Nescip Store tidak merasakan adanya masalah yang menghambat proses produksi produk rak pot bunga. Namun saat tim penulis mengamati kegiatan produksi Nescip Store, tim penulis menemukan beberapa masalah. Pertama, tim produksi tidak memiliki standar operasional prosedur (SOP) dalam memproduksi produk rak pot bunga. Tidak adanya SOP membuat setiap hasil produksi memiliki output dan kualitas yang berbeda-beda karena tidak adanya ketentuan-ketentuan yang menjadi dasar dalam memproduksi rak pot bunga. Kedua, tim produksi tidak memiliki contoh usaha yang dapat dijadikan tolak ukur dalam memproduksi rak pot bunga. Awalnya tim produksi membuat rak pot bunga berdasarkan nilai tambah yang ingin diberikan, yaitu produk rak pot bunga berkualitas tinggi dengan harga yang ekonomis. Hal ini menyebabkan produk menjadi lebih berat karena menggunakan besi ukuran 10 dan memiliki ukuran yang besar (gambar 6). Akibatnya, ongkos kirim akan lebih mahal jika produk rak pot bunga dijual ke daerah di luar Cipunagara. 


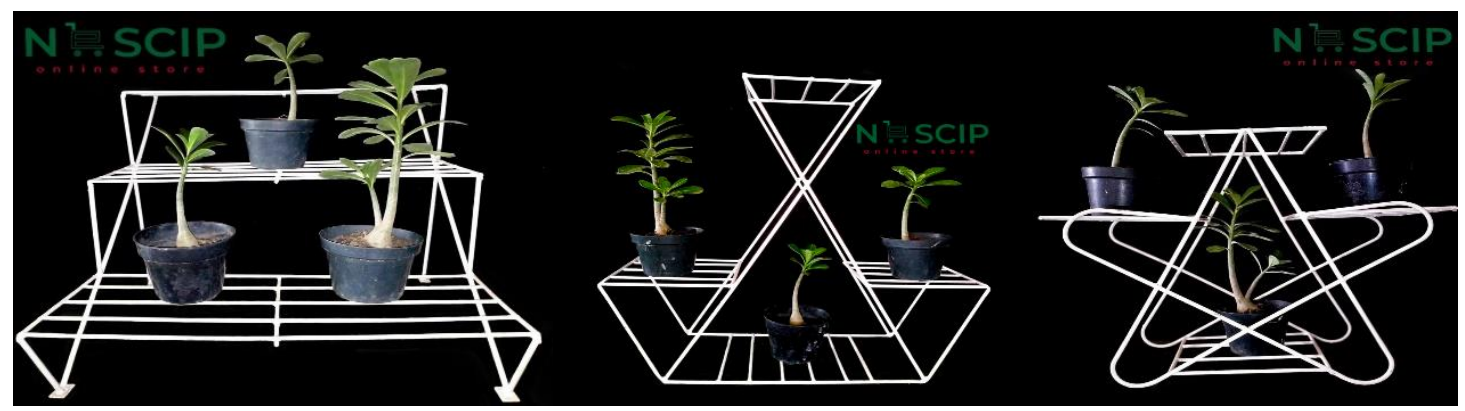

Gambar 6: Foto Produk Rak Pot Bunga

\section{Perbaikan Operasional}

Tim penulis mencanangkan dua strategi untuk melakukan perbaikan dalam sisi operasional Nescip Store. Strategi pertama yakni dengan membuatkan SOP produksi sederhana yang mudah dipahami oleh tim produksi anggota Nescip. SOP produksi memiliki tujuan untuk memastikan bahwa setiap bahan baku dapat digunakan untuk produksi rak pot bunga yang sesuai dengan standar mutu yang telah ditentukan. Strategi kedua, tim penulis melakukan riset pasar mengenai preferensi pasar terkait produk rak pot bunga yang menjadi minat masyarakat untuk dibeli secara daring. Riset pasar ini dijalankan melalui penyebaran kuesioner secara daring melalui platform Google Form. Tujuan lain dari riset pasar ini adalah untuk mengetahui kesulitan yang masih dialami oleh konsumen yang membeli rak pot bunga secara daring.

\section{Dampak Perubahan Operasional}

Usulan kegiatan yang diajukan oleh tim penulis menyesuaikan dengan TOWS Matriks pada kolom ST dan WT Strategies yaitu melakukan inovasi produk. Kegiatan pertama yang diajukan kelompok adalah menyusun SOP (gambar 7). Berikut rincian prosedur yang tim penulis susun untuk membantu tim produksi Nescip Store menjaga kualitas produknya:

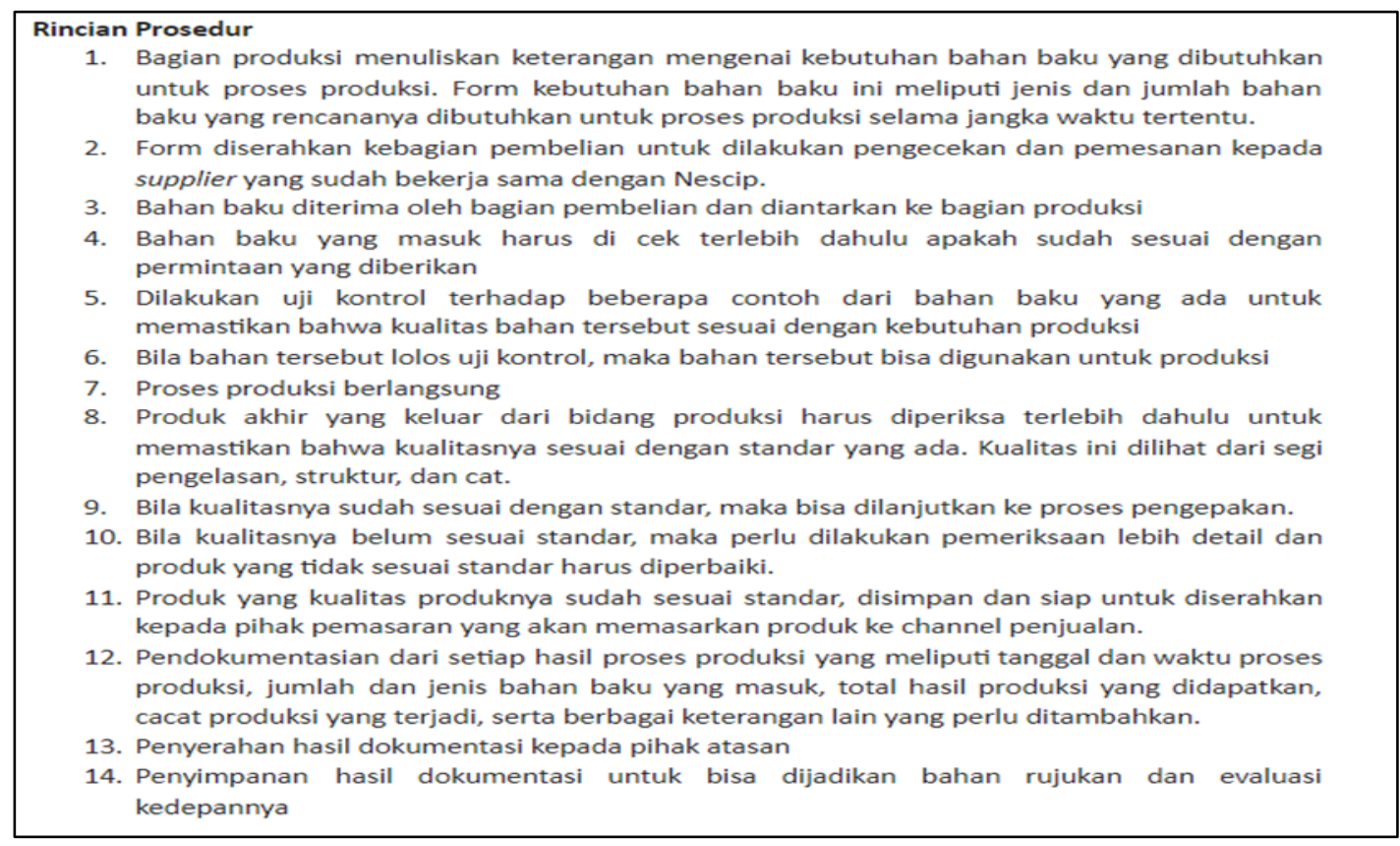

Gambar 7: Rincian Prosedur Proses Produksi Nescip Store 
Selain itu, Tim penulis juga membuatkan Rincian Kontrol Kualitas (Quality Check) seperti terlihat di gambar 8 .

\section{Standar Quality Check}

\begin{tabular}{|l|l|}
\hline \multicolumn{1}{|c|}{ Aspek } & \multicolumn{1}{c|}{ Keterangan } \\
\hline Pengelasan & 1. Hasil las kokoh dan rapi. \\
\hline Struktur & $\begin{array}{l}\text { 1. Besi lurus dan dapat berdiri tegak. } \\
\text { 2. Siku dan lengkung memiliki bentuk yang rapi. }\end{array}$ \\
\hline 3. Potongan rapi, tidak miring, serta sudut yang tidak tajam.
\end{tabular}

Gambar 8: Standard Quality Check Nescip Store

Selanjutnya tim penulis juga menyusun standar pengemasan produk dalam dua cara, yakni menggunakan jasa pengiriman dan pengiriman sendiri:

\section{Standar Pengemasan Produk}

Dengan Jasa Pengiriman:

1. Produk yang akan dikirim harus sudah melewati tahapan quality check.

2. Bagian siku yang mudah terbentur tertutup dengan karton/kardus.

3. Dilapisi dengan bubble wrap yang erat menggunakan lakban.

4. Melampirkan keterangan penerima dan tulisan "Jangan Dibanting" untuk keamanan produk selama dalam perjalanan

5. Mengirim produk dengan jasa pengiriman yang dipilih oleh konsumen atau yang terpercaya

\section{Pengiriman Sendiri:}

1. Produk yang akan dikirim harus sudah melewati tahapan quality check.

2. Siku-siku produk yang mudah terbentur dilapisi dengan karton/kardus

3. Produk dibungkus dan diikat dengan plastik yang menutupi semua bagian pada produk.

4. Maksimal 2 produk untuk diangkut menggunakan motor, lebih dari 2 menggunakan pick up.

5. Produk dipastikan aman selama perjalanan. Jika barang berukuran besar (lebih dari $150 \mathrm{~cm}$ ) dapat menggunakan mobil pick up.

Gambar 9: Standar Pengemasan dan Pengiriman produk Nescip Store

Strategi kedua, tim penulis membuat survei untuk mengetahui preferensi konsumen tentang rak pot bunga. Tabel 3 menunjukkan jawaban yang paling sering muncul dari hasil survei. 
Tabel 3: Kendala dalam pembelian daring produk Rak Pot Bunga

Menurut Anda, apa yang menjadi kendala bagi Anda untuk membeli rak pot bunga secara daring?

Tidak dapat melihat produk secara jelas ukuran dan bentuk aslinya, hanya mengandalkan foto Biaya ongkir yang mahal ke luar kota

Khawatir barang sampai rumah dalam kondisi cacat karena proses pengiriman yang tidak tepat

Tim penulis memberikan rekomendasi untuk tim produksi Nescip membuat produk "rak pot bunga bongkar pasang" untuk mengatasi kendala yang kerap dirasakan konsumen, yakni biaya ongkos kirim yang mahal. Berikut adalah bentuk dari rak pot bunga bongkar pasang yang diproduksi oleh Nescip:

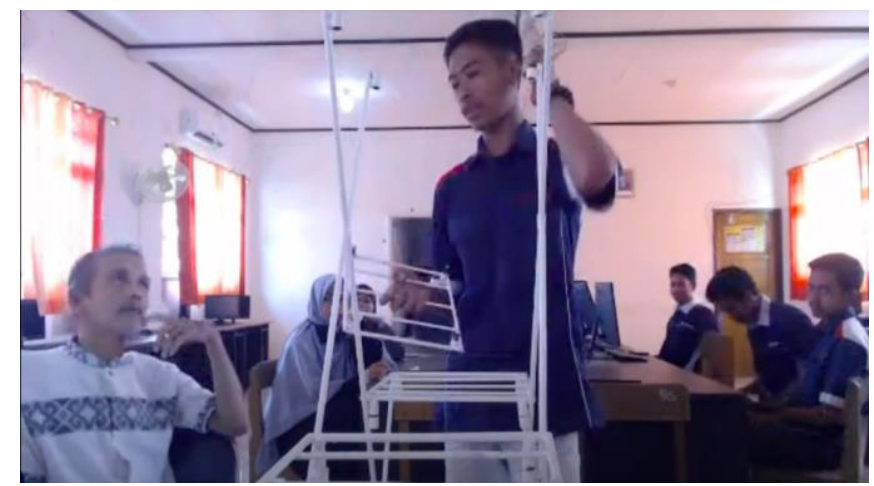

Gambar 10: Produk Rak Pot Bunga Lipat Nescip Store

\section{Lokakarya Minat Berwirausaha}

Minat berwirausaha perlu ditumbuhkembangkan sejak dini. Peserta didik di SMKN 1 Cipunagara perlu dibekali dengan pengetahuan kewirausahaan, agar mampu mengembangkan produk hasil praktik kerja di berbagai jurusan SMKN 1 Cipunagara. Tim penulis juga mengadakan program lokakarya dengan judul "The Next Juragan Muda". Program ini dilaksanakan melalui media komunikasi Zoom Meeting dari tanggal 20 - 23 Februari 2021 sebagai upaya untuk memberikan wawasan kewirausahaan bagi peserta didik diluar tim produksi Juragan Muda Nescip. Wawasan kewirausahaan dimulai dari semangat seseorang untuk memulai usaha, ditambah dengan kondisi lingkungan yang mendukung usaha. Simulasi kompetisi usaha dan lokakarya pengembangan produk adalah salah satu kondisi lingkungan yang dapat meningkatkan minat berwirausaha (Hermuningsih \& Kurniawan, 2019; Jaharuddin et al., 2019; Soputan et al., 2019).

\section{Kegiatan Lokakarya}

Konsep acara dari program "The Next Juragan Muda" adalah pemberian materi bertema wirausaha. Peserta didik selain mendapatkan pengetahuan baru, juga mendapatkan pengalaman langsung berkompetisi, serta mendapatkan gambaran bagaimana proses berdirinya sebuah usaha dan proses usaha yang berjalan baik maupun gagal. Kegiatan lokakarya dibagi menjadi tiga bagian, yakni: 
1. Pre-event: Tim penulis menyebarkan link film edukasi kepada peserta yang akan mengikuti program, dengan tujuan menjaring calon peserta didik mengikuti kegiatan lokakarya.

2. Event: Penulis mengundang pembicara yaitu seorang dosen kewirausahaan di Universitas Prasetiya Mulya. Bapak Iwan Kahfi menyampaikan materi terkait minat berwirausaha dan beberapa pengetahuan seputar bisnis. Bapak Iwan juga bertindak menjadi juri untuk kegiatan lomba selanjutnya.

3. Post-Event: Setelah pemberian materi kewirausahaan, diadakan lomba ide bisnis. Lomba ini diikuti oleh kelompok yang berisikan 2-3 orang peserta lokakarya. Ide bisnis kemudian dipresentasikan kepada tim juri.

Berikut dokumentasi dari kegiatan The Next Juragan Muda yang antusias diikuti oleh sejumlah peserta didik:

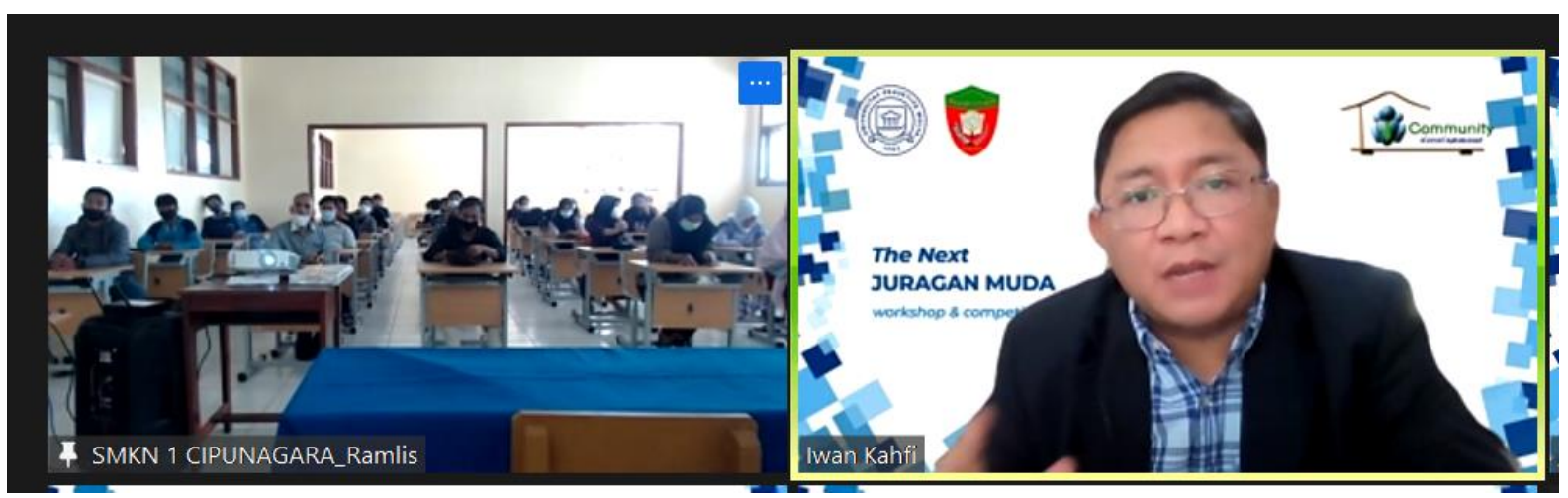

Gambar 11:Pemaparan Materi oleh Pak Iwan Kahfi

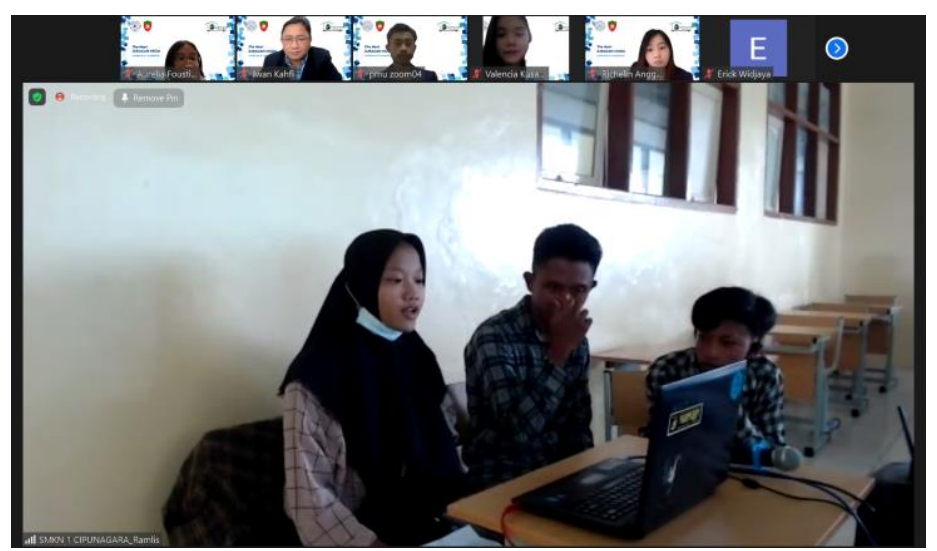

Gambar 12:Presentasi Kelompok dari SMKN 1 Cipunagara

Berbagai pelatihan kepada mitra dan peserta didik SMKN 1 Cipunagara menjadi dasar bagi mitra untuk mengembangkan usaha rak pot bunga. Sesuai dengan arahan Menteri Menteri Koperasi dan Usaha Kecil Menengah Bapak Teten Masduki, edukasi literasi bagi SDM menjadi salah satu dari permasalahan utama yang dihadapi oleh UMKM di era digital (Amalia, 2021). Melalui program COMDEV, tim penulis berharap usaha Juragan Muda Nescip dapat berkembang dengan memperhatikan aspek produksi, pemasaran dan keuangan. 


\section{Simpulan dan Rekomendasi}

Kegiatan pengembangan UMKM dalam program COMDEV Universitas Prasetiya Mulya tahun 2021 memiliki sejumlah mitra usaha, dan mitra dalam tulisan ini berasal dari SMKN 1 Cipunagara Subang. Mitra memiliki usaha “Nescip Store”yang menjual rak pot bunga dari besi hasil karya siswa/i jurusan Teknik Pemesinan.

Program pendampingan berfokus memberikan mitra beberapa gagasan yang bermanfaat untuk keberlanjutan usaha. Pada bidang keuangan, dengan adanya perbaikan dan pelatihan sistem pencatatan keuangan yang tim penulis berikan, diharapkan mitra dapat mengambil keputusan manajemen keuangan dengan lebih baik. Dari sisi pemasaran, tim penulis merekomendasikan pembuatan beberapa jalur pemasaran mulai dari website, Instagram, dan akun shopee, agar mitra tidak hanya mengandalkan pemasaran secara konvensional. Selanjutnya pada sistem operasional, kinerja bagian produksi diharapkan dapat berjalan lebih teratur dengan disediakannya SOP yang menjadi landasan standar kualitas produk. Lokakarya "The Next Juragan Muda" juga diadakan untuk menjaring minat wirausaha peserta didik SMKN 1 Cipunagara.

Program Pendampingan ini tentu menghadapi berbagai kendala saat pelaksanaannya. Kendala yang dihadapi adalah sulitnya berkomunikasi dengan mitra melalui sistem daring. Hal ini dikarenakan keterbatasan jaringan internet di daerah mitra yang masih belum memadai dan seringkali menghambat proses komunikasi. Selain itu, waktu pelaksanaan program pendampingan intensif dan lanjutan ternyata juga bersamaan dengan periode ujian sekolah tingkat SMA. Hal ini menyebabkan pertemuan daring maupun komunikasi yang dijalankan pada bulan April- Mei 2021 banyak yang harus tertunda karena bersamaan waktunya dengan ujian sekolah. Tim Juragan Muda Nescip yang terdiri dari para guru yang ditunjuk dan peserta didik kelas 12, harus banyak beradaptasi dengan berbagai kendala ini. Tim penulis merekomendasikan pemilihan guru dan peserta didik dari kelas lain agar tidak mengganggu proses belajar mengajar di tingkat sekolah untuk kegiatan COMDEV di masa mendatang.

\section{Penghargaan}

Berbagai pengalaman baru telah kami dapatkan melalui kegiatan COMDEV 2021. Termasuk belajar cara berinteraksi dengan masyarakat di luar lingkungan sosial tim, dan juga memperoleh pemikiran dari perspektif bisnis yang berbeda. Tentunya, program pendampingan ini tidak akan terlaksana tanpa adanya dukungan dari berbagai pihak yang telah berkontribusi dalam keberlangsungan program, diantaranya:

- Tim PPUK Universitas Prasetiya Mulya yang telah merancang konsep program pendampingan ini serta menghubungkan kami dengan mitra usaha.

- DPL dan Fasilitator yang telah membantu memberikan masukan dan saran kepada kelompok kami dalam mempertimbangkan program yang dicanangkan dan membantu kami ketika mengalami kesulitan.

- Bapak Iwan H Kahfi, MBA yang telah bersedia menjadi pembicara pada program sekunder berupa seminar kewirausahaan sekaligus menjadi juri kompetisi bisnis yang diadakan dalam rangkaian acara tersebut. 


\section{Daftar Pustaka}

Almanei, M., Salonitis, K., \& Xu, Y. (2017). Lean Implementation Frameworks: The Challenges for SMEs. Procedia CIRP, 63, 750-755. https://doi.org/10.1016/j.procir.2017.03.170

Amalia, N. S. (2021). Menkop Ungkap Tantangan UMKM di Era Digital dan Strateginya. DetikFinance. https://finance.detik.com/berita-ekonomi-bisnis/d5605605/menkop-ungkap-tantangan-umkm-di-era-digital-dan-strateginya

Azizah, N. L., \& Mauliana, M. I. (2020). Program Pengabdian Masyarakat Usaha Mikro Kecil Menengah ( Umkm ) Mengenai Desain. Jurnal ABDI, 6(1), 58-64.

Badan Pusat Statistik. (2020). Katalog: 3101028. In Analisis Hasil Survei Dampak COVID19 terhadap Pelaku usaha.

Chaffey, D., \& Ellis-Chadwick, F. (2015). Digital Marketing (7th Editio). Pearson Education.

Fitriasari, F. (2020). How do Small and Medium Enterprise (SME) survive the COVID19 outbreak? Jurnal Inovasi Ekonomi, 5(02), 53-62. https://doi.org/10.22219/jiko.v5i3.11838

Hermuningsih, S., \& Kurniawan, V. R. B. (2019). Penerapan Program Pengembangan Kewirausahaan (PPK) Untuk Meningkatkan Kuantitas Usaha Rintisan Mahasiswa Di Universitas Sarjanawiyata Tamansiswa Yogyakarta. Jurnal Pengabdian Masyarakat IPTEKS, 30. https://doi.org/10.32528/pengabdian_iptek.v5i1.2157

Jaharuddin, J., Purnawan, I., Mujiastuti, R., Muthmainnah, R. N., \& Prasetyawati, M. (2019). Strategi Melahirkan Mahasiswa Pengusaha Pemula (Studi Kasus Mahasiswa Universitas Muhammadiyah Jakarta). Jurnal Kewirausahaan Dan Bisnis, 24(13), 25. https:/ / doi.org/10.20961/jkb.v24i13.29310

Lynch, W. (2020). Strategic Planning to Actionable Items: From SWOT to TOWS Analysis. Medium.Com.

Mudjijah, S., \& Anggraini, T. (2021). Pendampingan Kewirausahaan bagi Usaha Mikro, Kecil dan Menengah di Kecamatan Ciledug Kota Tangerang. Jurnal Abdimas BSI: Jurnal Pengabdian Kepada Masyarakat, 4(1), 119-127. https://doi.org/10.31294/jabdimas.v4i1.9596

Mulyani, A. S., Nurhayaty, E., \& Miharja, K. (2019). Penerapan Pencatatan dan Laporan Akuntansi Pada Usaha Mikro Kecil Dan Menengah (UMKM). Jurnal Abdimas BSI: Jurnal Pengabdian Kepada Masyarakat, 2(2), 219-226. https://doi.org/10.31294/jabdimas.v2i2.5818

Oktaviani, F., \& Rustandi, D. (2018). Implementasi Digital Marketing dalam Membangun Brand Awareness. PRofesi Humas: Jurnal Ilmiah Ilmu Hubungan Masyarakat, 3(1), 1. https:/ / doi.org/10.24198/prh.v3i1.15878 
Pearce, A., Pons, D., \& Neitzert, T. (2018). Implementing lean-Outcomes from SME case studies. Operations Research Perspectives, 5, 94-104. https://doi.org/10.1016/j.orp.2018.02.002

Rosyadi, I. (2013). Strategi Pengembangan Usaha Mikro Milik Mahasiswa. Jurnal Manajemen Dan Bisnis, 17(2), 112-122.

Schermerhorn, J. R., \& Bachrach, D. G. (2015). Introduction to Management. Wiley. https://books.google.co.id/books/about/Introduction_to_Management.html?i $\mathrm{d}=$ wixEDwAAQBAJ\&redir_esc $=y$

Septiani, Y., Sugiharti, R. R., \& Setyawan, S. (2020). Pelatihan Pembukuan dan Operasional Koperasi Madrasah Ibtidaiyah Dalam Rangka Perbaikan Kesejahteraan Guru Se-Kecamatan Secang, Kabupaten Magelang. Jurnal Abdimas BSI: Jurnal Pengabdian Kepada Masyarakat, 3(1), 25-32. https://doi.org/10.31294/jabdimas.v3i1.6534

Soputan, G. J., Mamuaja, N. C., Ohy, J., \& Krisnanda, M. (2019). Program Pengembangan Kewirausahaan di Fakultas Ekonomi Universitas Negeri Manado. Jurnal Kewirausahaan Dan Bisnis, 24(Xiv), 100-108. 